\title{
USING NON-MEGA EVENTS FOR DESTINATION BRANDING: A STAKEHOLDER PERSPECTIVE
}

\author{
Janice HEMMONSBEY \\ University of Johannesburg, School of Tourism and Hospitality, \\ College of Business and Economics, South Africa, e-mail: janicehemmonsbey@yahoo.com
}

Tembi M. TICHAAWA*

University of Johannesburg, School of Tourism and Hospitality, College of Business and Economics, South Africa, e-mail: tembit@uj.ac.za

\begin{abstract}
Citation: Hemmonsbey, H., \& Tichaawa, T.M. (2019). USING NON-MEGA EVENTS FOR DESTINATION BRANDING: A STAKEHOLDER PERSPECTIVE. GeoJournal of Tourism and Geosites, 24(1), 252-266. https://doi.org/10.30892/gtg.24120-357
\end{abstract}

\begin{abstract}
Stakeholders of destinations play an important role in the development and function of destination brands. They have increasingly recognised the importance of sport for the development of destination brands. However, challenges in stakeholder coordination and collaboration in the utilisation of sport for brandrelated benefits still persist. This study explores the destination brand of South Africa and determines the strategic stakeholder relationships in the utilisation of non-mega events for destination brand development. A qualitative design featuring semistructured, in-depth, face-to-face interviews was conducted with definitive sport, tourism and destination-brand stakeholders. A thematic analysis of results clearly revealed the role of stakeholders in sport and tourism relations in the promotion of the South African brand through sport event hosting. The results further show that key challenges exist in the objectives of stakeholders in public and private entities that appear to stifle effective partnering and that, essentially, further impede effective collaboration in sport event leveraging. The paper adds value particularly to the stakeholders of a developing destination brand context towards informing and guiding them on views and perceptions in relation to strategies for effective stakeholder relations when utilising non-mega events for effective destination branding.
\end{abstract}

Key words: Destination branding, non-mega sport event, tourism, stakeholder perceptions, South Africa

\section{INTRODUCTION}

The use of events, especially sport tourism events, for the purpose of destination branding has been of increasing interest among academics and practitioners. According to Getz and Page (2016), events are not only animators of the destination's attractiveness, but, more fundamentally, are key marketing propositions in the promotion of places,

\footnotetext{
* Corresponding author
} 
especially given the increase in globalisation to attract global tourism and to increase visitor spending. Todd et al. (2017) note that hallmark events, in particular, have been recognised as valuable assets for destinations that manage event portfolios, as they make a significant contribution to the tangible and intangible aspects of event tourism. Thus, in terms of the current scene of sport event tourism, the development of destination brands has become a strategic tool, as a result of the increasing competition and the augmented brand-related benefits for destinations (Garcia et al., 2012). For instance, Australia strategically utilised the 2000 Olympic Games to position itself as a global destination for events. More critically, through the effective leveraging of the Games, various groups of stakeholders expediently planned for sustainable economic benefits through regular tourism, long after the hosting phase (Chalip, 2004). Indeed, O'Brien and Chalip (2008) note that, since the Australian case, it has become common for stakeholders to accompany mega-events with strategic leveraging programmes. For example, at the 2002, 2006 and 2010 Commonwealth Games, held in Manchester, Melbourne and New Delhi, respectively, as well as at the 2003 Brisbane Rugby World Cup, and at every Olympic Games since Sydney 2000, each host nation involved has employed the leveraging of programmes to enhance the host destination brand, and to foster tourism and business development.

Against such a backdrop in event leveraging, the significant role of stakeholders in destination banding practices through sport events is highlighted. However, as destination branding involves a multiple group of stakeholders (Fan, 2010; Hankinson, 2010), likewise does the sport event industry encompass a range of stakeholders who might have dissimilar views on how sport is used for destination branding. Nonetheless, the efforts exerted to utilise sport to promote the destination brand require the collaboration of a complex group of stakeholders in both sport and destination branding (Morgan et al., 2010). To the above-mentioned end, Todd et al. (2017) note that there is still limited understanding regarding stakeholder engagement with sport events over time; limited knowledge on the stakeholders' lived experience in event tourism; and consequent management implications. Thus, one of the key challenges for the effectiveness of the utilisation of events for tourism and destination branding is the poor coordination among the stakeholders (Todd et al., 2017). The current study, therefore, introduces the views and challenges of stakeholders in sport, tourism and destination branding during the hosting of non-mega sport events, for the purpose of achieving destination branding benefits. Moreover, the study reveals stakeholder strategic objectives, as well as details strategies for the utilising and leveraging of sport for destination brand development, albeit in the developing South African context.

\section{DESTINATION BRANDING THROUGH SPORT}

The branding theory has advanced from its origins in the marketing arsenal of contemporary markets to the branding of places and destinations especially. As a result of such advancement, the role of brands has evolved from the mere giving of a brand name to a product. Brands are considered a direct consequence of strategic market segmentation and product differentiation (Xie \& Boggs, 2006), and they have been conceptualised by De Chernatony and Riley (1998), Louro and Cunha (2001), Wood (2000) and De Chernatony and Segal-Horn (2001) as communication devices, in terms of their identity (logo, slogans and trademarks); as perceptual entities referring to brands appealing to consumer senses and emotions; as value enhancers leading to brand equity; and as relationships communicating the brand personality. Interestingly, Hankinson (2004) grounds the concepts in destination brands that consequently corroborate the similarity in brands across a variety of different environments. Sport has proven to be a powerful industry for promoting tourism (Tichaawa \& Bama, 2012; Nyikana \& Tichaawa, 
2018a) and for positioning destination brands (Anholt, 2005; Freire, 2014; Mohammadi \& Jazaei, 2016). Certainly, sporting events, in particular, are considered important pull factors (Turco et al., 2012) that generate opportunities for destination brand awareness through sponsorships and broadcasts, as well as for economic development through visitor spending on a destination's offerings, job creation, and sport business opportunities (Higham \& Hinch, 2009; Tichaawa \& Bob, 2015; Tichaawa et al., 2018). Moreover, sport events play a critical role in shaping national and local tourism products, with them having an ability to transform destinations (Nyikana \& Tichaawa, 2018b). For example, such major events as the 1995 Rugby World Cup and the 2010 FIFA World Cup have consistently proved the above for South Africa's brand transformation as it emerged from its outdated segregated brand pre-apartheid (Bob \& Swart, 2010; Cornelissen et al., 2011; Knott et al., 2013; Hemmonsbey \& Tichaawa, 2018). As the global competition for prominence among destinations has intensified, there has been growing awareness of the significant impact of sport events on a destination's image (Hemmonsbey et al., 2018). The above has been particularly achieved through the media coverage of such sport megaevents as the Olympic Games and other international events (Chalip et al., 2003). However, there are some concerns around the degree to which the hosting of sport events enhances the host destination's brand image, and, subsequently, the extent to which the event stimulates the economy through travel behaviour post-event hosting (Chalip et al., 2003; Kaplanidou, 2007; Kaplanidou \& Gibson, 2010; Gibson et al., 2008). Thus, the debate over the long-term economic and tourism benefits of sport event hosting, despite the benefits of travel intention as a result of destination brand image, continue to evolve between stakeholders, especially political groups and event organising committees.

While the above debate typically applies to the mega-event or hallmark event, Taks (2013) explains that non-mega events are significantly different from mega-events with regards to their effect on the local host community. The former sport events are generally smaller in size, scale, scope, and reach than are their mega counterparts, like the Olympic Games, the World Cup, the Euro Cup, and the Commonwealth Games (Taks et al., 2015). Through the hosting of non-mega events, there is seemingly great potential for establishing tighter social networks and connections than before with the local community and stakeholders regarding the event, no matter whether the stakeholders involved are politicians, spectators, volunteers, destination marketing managers, or event organisers (Taks et al., 2015). In addition, with regards to the event venues and the marketing of events, Taks et al. (2015) point out that the relatively small-scale non-mega event tends to use comparatively small-scale facilities, and it does not require an expensive infrastructure. Such types of small-scale events also create opportunities for sustainable local partnerships, and for enhanced coordination efforts, between the event organisers and their partners which, from a local community hosting and marketing perspective, makes non-mega events uniquely different to the mega-event, which is accompanied by a huge cost of hosting, and by exclusive marketing activities. In addition to capitalising on event tourism and media as opportunities for destination branding through sport events, the traditional event leveraging research by Chalip (2004) suggests that, in regards to the non-mega event, the consideration that is given to relatively strong social networks, and to sustainable local partnerships, must be included in the key strategic prospects. Thus, it can be posited that small-scale non-mega sport events create opportunities for the leveraging of sustainable local partnerships, and for the enhancing of coordination efforts between the event organisers and their partners (Taks et al., 2015).

Notwithstanding such opportunities and strategic prospects, Smith (2014) poses a question related to the responsibility of formulating and implementing effective leverage initiatives. According to the aforementioned author, event leverage initiatives are separate 
from, despite them being related to, the delivery and management of event projects, making it difficult to assign responsibility for the formulation and implementation of the projects to an entire range of stakeholders. For the above-mentioned reason, Smith (2014) suggests that organisations with expertise in specific policies, such as social, economic or environmental ones, should take responsibility regarding the implementation and management of projects linked to their respective mandates. For example, in the case of a project being linked to a social objective, it should be led by the local authorities with the desired social mandate and expertise. Similarly, economic projects should be the responsibility of local economic partnerships. Kellett et al. (2008) discuss the example of the 'Green City' initiative, as it was pursued by the City of Vancouver in tandem with the 2010 Winter Olympic Games, which was specifically led by experts in the local leadership authority. Also, the 'Adopt a second team' initiative, which was pursued by the Melbourne municipal authorities in conjunction with the 2006 Commonwealth Games, saw stakeholders in the municipality leading the initiative. Smith (2014), however, recognises that, since the leveraging of projects relies, to a degree, on the actual event itself, there should be some formal involvement from the local organising committees or event organisers. While their involvement is limited to the event hosting, they tend not to be responsible for leading the long-term sustainability efforts that are directed towards social and economic development. Thus, for the non-mega event, the debate around the long-term sustainability of destination brand development exists in terms of the responsibility of stakeholder groups to implement sustainable programmes.

\section{STAKEHOLDER ANALYSIS IN STRATEGIC DESTINATION BRANDING Stakeholder theory}

Essentially, the stakeholder concept holds that an organisation occupies the centre of a network of relationships that it has with various interested parties (Donaldson \& Preston, 1995; Sheehan et al., 2007; Hankinson, 2010; Fyall, 2011; Houghton \& Stevens, 2011). In their formative work on the stakeholder theory, Sheehan et al. (2007) claim that, in developing the stakeholder theory, efforts were made to explore issues of stakeholder identification, analysis and management. With regards to the stakeholder identification, Donaldson and Preston (1995, p. 67) posit that stakeholders are identified as "persons or groups with legitimate interests in the procedural and/ or substantive aspect of corporative activity", regardless of whether the corporation concerned has any corresponding functional interest in them. Clarkson (1995) explains that stakeholders need to be identified by their primary and secondary influences on organisations.

For instance, primary stakeholders are those that affect, and who are affected by, the survival of the organisation, whereas secondary stakeholders are those that influence, or affect, the organisations. However, unlike primary stakeholders, they do not engage in transactions with the organisations involved, and they do not affect the livelihood of the organisations concerned. Although no definitive list of stakeholders is identified in the destination branding literature, Sheehan et al. (2007), Houghton and Stevens (2011) and Ooi and Pedersen (2010) particularly note the following stakeholders in the involvement of branding destinations: the local residents; the community; the local, regional and national authorities; and the destination marketing organisations (DMOs), which, as a result of their significant influence in destination brand development, could be viewed as being the primary stakeholder groups. To the above-mentioned list of stakeholders, Morgan et al. (2003) add environmental groups and agencies, as well as trade associations and the wider private sector, which can then be regarded as secondary, due to their ancillary influence on the development of the destination brand, especially through the utility of sport. In addition to the stakeholders identified for destination 
branding, and more specific to the context of the current study, the stakeholders concerned in major sport are identified, in particular, in terms of their role in event organising and in the strategic planning and marketing of events for brand-related benefits.

After the relevant stakeholders have been identified and differentiated, Sheehan et al. (2007) advocate for management to employ appropriate strategies that will guide their interaction with the other actors. The researchers concerned note that successful stakeholder management has the potential to lead to the establishment of substantial competitive advantage, through the forming and maintenance of relationships. They further argue that the support of all stakeholder groups is necessary for the continued survival of an organisation (see also Waligo et al., 2013; Todd et al., 2017). More specific to destinations, Morgan et al. (2003) point out that the management of stakeholders has to be proactive, with particular attention being given to the development of partnerships. It is, therefore, imperative that the relevant stakeholders should agree on the final vision statement that will provide a meaningful and operational 'dream' for the future of their destination, being one that reflects the values of the destination stakeholders, while not ignoring the realities and constraints of the marketplace (Morgan et al., 2003). Morgan et al. (2003) and Paskaleva-Shapira (2007), however, present a challenge for destination marketers to make the destination brand 'live' for visitors, so that they can experience the promoted brand value and the unique authenticity of the place. They state that, in such an undertaking, DMOs are vulnerable to a variety of political pressures and that they, therefore, have to reconcile a range of local and regional interests and promote an identity that is acceptable to a number of stakeholders. To the above end, the suggestion to DMOs, which can also present a challenge, is to search for strong brands that add value by answering to what people want and to what is relevant to them; finding out, and differentiating, what the city can offer; and making strategic decisions (Paskaleva-Shapira, 2007).

\section{Stakeholder challenges in utilising sport events for destination brand development}

According to Palmer (2002) and Morgan et al. (2003), tourism destinations are, arguably, one of the most difficult 'products' to market, as they involve a large number of stakeholders and a brand image over which DMOs have very little control. Morgan et al. (2002) posit that, regardless of where destinations are in their life cycle, compared to product and service brands, DMOs face peculiar branding challenges, including in terms of the number of multi-stakeholder groups that destinations have to consider. Consequently, destinations involve a high degree of complexity and fragmentation, made up of complex entities, collections of individuals and communities, with the actions of the interdependent, multiple stakeholders impacting on the rest of the actors in the community (Lichrou et al., 2010). For all intents and purposes, the challenge is that the branding of destinations needs to unite independent groups of various stakeholders in collaborating, as well as to negotiate the interests of various parties. For the abovementioned reason, Lichrou et al. (2010) note that place and destination marketers have expressed an interest in the concept of stakeholders.

Previous research on stakeholder roles in destination branding practices has shown that stakeholder commitment to collaboration, and, moreover, their prioritisation of investment in sport events hosting, as well as, more importantly, their implementation of leveraging activities, for tourism and destination branding benefits remain a concern among the stakeholders in developing nations, as is the case with South Africa (Hemmonsbey \& Knott, 2016). The above is likely to affect the nation's competitive brand positioning, especially as destinations tend to depend on such collaborations to survive, in the face of increasing competition and environment challenges (Allan, 2011). Elsewhere, in the case of a developed nation, it is clear that Australia and the 2000 Olympic Games 
achieved global benefits linked to tourism, investment, and business, for their destination brand development, as a result of effective stakeholder collaborations through partnerships and investment in the strategic utilisation of sport through event leveraging. For the above-mentioned reason, Trueman et al. (2004) postulate that stakeholder collaborations through effective partnerships can be achieved through the context of sport and, in particular, the sport events, for destination-brand-related benefits. PaskalevaShapira (2007) further posits that partnerships between the private and public sectors, for instance, are considered effective means of achieving destination competitiveness, as a result of the multiplicity of industries (both sport and tourism) involved in creating and sustaining destinations' competitiveness (also see Nyikana \& Tichaawa, 2018b; Ilieș et al., 2016; Ilieş et al., 2018). What is more, the importance of pre- and post-event stakeholder engagement through sport event leveraging, especially in terms of building local brand awareness and preparedness, as well as through establishing networks and linkages among key stakeholders who might benefit not only the event, but also the destination brand, is advocated (Munien \& Majola, 2012). With the increasing interest from stakeholders in the developing nations in participating in globalisation, and, particularly, in using sport for tourism- and destination-branding benefits, the key question that remains relates to the effective coordination among the stakeholders concerned for the effective utilisation of events to achieve such benefits. Consequently, the current study introduces the views and challenges of stakeholders in sport, tourism and destination branding during the hosting of non-mega sport events for the purpose of achieving destination branding benefits. The study focuses on examining stakeholder objectives, as well as on determining stakeholder strategies for the utilising and leveraging of non-mega sport events for destination brand development. An investigation into the South African brand presents empirical findings from a developing destination perspective.

\section{THE RESEARCH STUDY}

The current study adopted a qualitative research approach, in terms of which indepth, semi-structured interviews were conducted with key industry stakeholders representing local and national (public and private) sport, tourism and destination branding entities. Such entities consist of, for example, local sport and event organisers, city and national departments of sport and recreation, city and national tourism and destination marketing organisations, private tour operators, as well as sport tourism investment organisations. Respondents representing the organisations were purposefully selected by virtue of their leadership roles and characteristics, which had some bearing on their perceptions and experiences of branding South Africa through major sport events. From a city and national perspective, stakeholders provided insight into strategies for sport event leveraging for destination brand development. From a sport event organising and investment perspective, such respondents reported on their experiences on the strategic planning and marketing of major sport and events, alongside the objectives of national policy on sport event leveraging. Similarly, the private sport tourism operators provided insights into the knowledge and experiences operating in the field of sport tourism activations during the hosting of sport events. More specifically, all the respondents were sought from top management positions, preferably at the level of chief executive officer (CEO), director or senior manager. Having a geographical spread of cities representing not only their municipalities, but also the overall South African brand, was important. Thus, the stakeholders were chosen from within South Africa's major sporting metros (i.e. Port Elizabeth, Cape Town, Johannesburg, Durban, and Bloemfontein). In addition to purposive sampling, it was important for the study to select key informants, based on the selected stakeholder theory underpinning the individual and 
collaborative 'stake' and influence that each organisation held in the destination branding outcomes, in terms of the hosting of non-mega sport events in South Africa. The aim for the study was to gain a broad overview of stakeholder perspectives on key concepts and to gather rich and meaningful data, thus the selected sample size of 24 was used.

All the interviews were conducted with the prior consent of the respondents. Each interview was conducted at a location chosen by the respondents, which was usually their workplace. All the interviews were digitally recorded and manually transcribed verbatim by the researchers. Every effort was made to ensure the validity and the reliability of the data through the constant checking of the interview transcripts, along with comparing them to the voice recordings and the field notes made during the interviews. The semistructured interviews were guided by a set of questions related to topics identified through the literature review. The interview protocol consisted of open-ended questions that allowed the interviewer to probe, or clarify, and to explore the particular areas of experience, or expertise, of the respondents. The overall focus of the interview schedule was geared towards exploring general concepts on destination branding and the utilisation of major events, in particular those promoting the South African brand. In addition, strategic stakeholder relationships and engagements in sport event hosting and leveraging were key areas of focus. The coding of the data was assisted by the software program called 'Atlas ti', which also assisted in the reduction and display of the data. The software program further served useful as a storage and reference facility for all the transcribed interviews. An inductive bottom-up approach followed, with individual codes being developed from key words, as each response was reviewed. From the resultant long list of codes, themes were developed and grouped that subsequently formed the basis of the results and discussion that are presented below.

All the responses are designated by an ' $R$ ', and by a specific number distinguishing the respondents from one another. The number held no significance either for the respondents, or for their affiliations. Such designation was done to protect the confidentiality of all the respondents who participated in the research. However, in some instances, an indication of an industry sector is given for the purpose of emphasising the responses obtained. Throughout the discussion, direct quotations are used to represent the original data gleaned. Each direct quotation was selected, based on the degree of its representation of a common response among the stakeholders, or on it clearly stating a core theme, or stating the key examples given as a particular point of discussion.

\section{RESULTS AND DISCUSSION}

\section{Destination branding of South Africa through non-mega events}

The respondents unanimously agreed on the significance of sport events for the development of South Africa's brand. Their sentiments consistently centred on the economic benefits gained through visitor spending and destination brand awareness opportunities emerging from tourism experiences. An excerpt illustrating the tourism and destination branding benefits as a result of the hosting of major sport events reads as follows:

The extraction of economic benefit for the local area [where the event is hosted], which is the municipality, and then South Africa on a global scale. So, if you don't get those benefits, including the branding benefits and international exposure benefits, then there is no reason to have the event (R4).

However, from an economic perspective, major sport event leveraging, according to O'Brien and Chalip (2008), should yield such long-term outcomes as the encouraging of repeat visitation, the reimaging of host communities in key markets, the fostering of 
business relationships, and the encouraging of inward trade, investment and employment. While the respondents in the study universally agreed with the views of O'Brien and Chalip (2008), in that major sport events "stimulate the economy, it stimulate[s] jobs [both temporary and permanent], and it stimulate[s] tourism growth" (R3), their responses neither included, nor confirmed, any evident long-term economic benefits obtained through major event hosting in South Africa. For the above-mentioned reason, the major event organisers, together with the key role players, tend to adopt a strategic approach towards prior planning of the hosting of events (Smith, 2014). An event stakeholder, who recognised their event as an opportunity for yielding long-term national and international tourism for the wider South African destination, suggested a strategic way forward. Thus, with regards to the leveraging of major sport events, in particular the Cape Town Cycle Tour, a key informant in sport event organising held that:

Using the [Cape Town] Cycle Tour as an example, it is not just coming to a bicycle race in Cape Town, that is the hook, it's [more like] going to Cape Town, then stop[ping] in Johannesburg on our way back [home] and spend[ing] a week at [the] Kruger National Park. It's about leveraging those opportunities (R2).

Certainly, from the data collected, other events also exist that could yield similar economic benefits for the South African brand. For example, events, sporting or otherwise, would enhance the "upstream tourism, [such as] catering, [the] hospitality industry, museums, and shopping malls, would be enhanced" (R4). Major events identified across the respondents within the various South African cities that are believed to contribute to the South African tourism and destination brand are outlined in Table 1.

Table 1. Major events contributing to the South African tourism and destination brand (Source: Authors, based on fieldwork)

\begin{tabular}{|l|ll|}
\hline \multicolumn{3}{|c|}{ Example of key major sport events in various South African cities } \\
\hline \multirow{4}{*}{ Representative host city } & \multicolumn{1}{c|}{ Major event } \\
\hline \multirow{4}{*}{ Cape Town / Western Cape province } & $\bullet$ & ABSA Cape Epic (off-road cycle race) \\
\cline { 2 - 3 } & $\bullet$ & Two Oceans Marathon \\
\cline { 2 - 3 } & $\bullet$ & Cape Town Cycle Tour \\
\cline { 2 - 3 } & $\bullet$ & Knysna Oyster Marathon \\
\cline { 2 - 3 } & $\bullet$ & Laingsburg Marathon \\
\cline { 2 - 3 } & $\bullet$ & Cup Met (horse race) \\
\cline { 2 - 3 } & $\bullet$ & Design Indaba (fashion and design exhibition) \\
\hline \multirow{2}{*}{ Johannesburg / Gauteng province } & $\bullet$ & Volvo \& Clipper Oceans Race \\
\hline \multirow{2}{*}{ Durban / KwaZulu-Natal province } & $\bullet$ & Telkom 94.7 Cycle Tour \\
\cline { 2 - 3 } & $\bullet$ & Soweto Marathon \\
\hline Port Elizabeth / Eastern Cape province & $\bullet$ & Durban July (horse race) \\
\hline \multirow{2}{*}{ Various South African cities } & $\bullet$ & Comrades Marathon \\
\cline { 2 - 3 } & $\bullet$ & Currie Cup (rugby) \\
\cline { 2 - 3 } & $\bullet$ & Sunshine Tour \\
\hline
\end{tabular}

What is significant from the above table is that key major events are not limited to sport, but also consist of cultural and festival events. Moreover, it is clear that the city of Cape Town is a key player in the hosting of major events, thus it should be considered immensely important for strategic leveraging though events, sporting and otherwise. All the events concerned are primary to the tourism and destination 
imperative of South Africa, as they are believed to yield maximum socio-economic benefits for their host communities and, arguably, through brand association, for the broader South African context. As a result, some of the major events mentioned form part of the event strategy of the local and national authorities, in positioning the destination as an 'Events Destination', or as a 'Gateway of Events' for Africa, which further positions the global competitive destination's brand.

\section{Clarifying stakeholder roles in the context of sport and destination branding}

The respondents were asked who they believed the key stakeholders involved in the major sport events for destination branding benefits were. Similar to the stakeholders involved in destination branding, as outlined by Sheehan et al. (2007), Houghton and Stevens (2011), and Ooi and Pedersen (2010), the following list of stakeholders became apparent through the stakeholder responses: the provincial and local government; various NGOs or charities that benefit from the sport itself; the private partners and the local communities/population; and a certain degree of national and international presence. However, the 'community', 'non-governmental organisations (NGOs)', and 'media' were uniquely mentioned in the context of a developing nation, with them also being perceived as key being role players in terms of sport event leveraging. Such entities differ from those that are typically stated in the developed destination context by such researchers as Chalip (2014). Moreover, the inclusion of 'sport event organisers' and of 'federations' as having a responsibility towards sport event leveraging, "due to the amount of sport brand sponsorships and television broadcasts that it attracts" is also unusual (R8). However, as Smith (2014) declares, the involvement of sport event organisers is limited to event hosting, and they are not responsible for masterminding long-term sustainability for social and economic development. Thus, the chief responsibility still lies with those who are operant in the local and national government organisations.

Although deemed significant, a key informant in local government held that, specific to tour operating companies, the group of stakeholders concerned tends to be absent or non-existent during the hosting of major events, which essentially impedes the effective utilisation of events for the efficacy of the destination brand. A key informant in local government intimated:

What I have noticed in and around cities is the lack of tour operators as a key roleplayer during major event hosting. They [the tour operating companies] can offer so much [in terms of] opportunities to show your guests the city and its attractions. That is where cities miss out on leveraging (R11).

The important role of media as a significant stakeholder was also emphasised, especially in the developing nation context. Consistent with the extant literature on the role of media in sport leveraging (see, for example, Brown et al., 2004; Higham \& Hinch, 2009; Jago et al., 2003), and with regards to the social media and brand exposure, the respondents expressed a belief that the social media played a "huge role in showcasing experiences in a particular destination" (R6), which, further, created brand awareness. Moreover, a key informant in sport event marketing considered that the social media might prove to be a highly valuable marketing tool for reaching a broad international audience. If they were used in such a way as to create 'nostalgia' or 'FOMO' (i.e. the fear of missing out), they could create an online following, and, subsequently, induce potential participation and future visits. However, a key informant in tourism and destination branding argued that "exposure means nothing until the eyeballs are converted into visitors" (R6), thus signalling the significance of capitalising on event tourism through the 
media as an opportunity for leveraging, as advocated for by Chalip (2004). Despite the important role of the media (both traditional and social) in creating brand awareness and online brand exposure, a few of the respondents argued that, specific to the South African context, "media is skewed in many cases" (R6). For example, a key informant in the local government argued:

Media and social media has [i.e. have] made all the issues of the country so prevalent, and it has become so visual and disturbing that there is little room for brand exposure in a positive way (R11).

Another key informant involved in tourism and destination branding admitted to the important role of such media, while acknowledging the skewed views that they portray of South Africa. This key informant expressed their view in the following way:

Media plays a very big role. The challenges that we [South Africans] have is that the media predominantly focus on the negatives and the sensational issues, which is not the total picture, and it is skewed in terms of representation of many negative incidents and very few positive incidents, where[as] the reality is just the converse (R6).

From an event leveraging perspective, Germany taught that media partnerships can be used to communicate positive messages about the destination brand image both pre- and post-event, through planned strategies relating to the destination (see Grix, 2012). Consequently, a concerted stakeholder effort is required, in the case of South Africa, to adopt the appropriate strategies and tactics for broadcasting messages that centre on new and innovative sport- and education-related projects, so as to instil a sense of confidence in the minds of potential future visitors.

\section{The key role of the local and national government in support of sport events for destination branding}

The data revealed distinct views from a sport event stakeholder concerning the level of support received from the national stakeholders, in particular those involved in the National Department of Tourism and Investment. A key informant in sport event marketing centred his deeply frustrated concern on the absence of funding and investment in major sport event marketing. While it is evident that major events, by their very nature, are organised, supported and hosted in and by the local municipalities, R2 believes that major events are driving national and international tourism, and, consequently, promoting the South African brand as a destination. For the abovementioned reason, the key informant in major event organising believes that National Tourism and Development is responsible for supporting and funding major events.

While no partnership exists around relating to such proposals from national government, it leaves event organisers with budgeting challenges around marketing activation programmes, both nationally and internationally. Consequently, the deeply frustrated key informant in sport event marketing responded:

The challenge I have as an event, is that I get no support from national tourism at all, [either from] national trade and industry [or from] national economic development. We are left to our own devices to promote the event to our international participants and partners, and subsequently [to] augment destination branding (R2).

A different key informant in sport event marketing shares the frustrating sentiments of R2, in that the national Department of Tourism can add more value to events if they work in tandem with private stakeholders and event organisers. While such frustrations were noted by various respondents, a key informant in sport events marketing had no proposal 
for a way forward, other than to engage regularly, and to discuss openly, opportunities for future strategic partnerships. An excerpt from his response reads as follows:

The involvement of national government is key in that they create many opportunities for expanding events. What happens is the proposals [for collaboration] get written up and presented, but sometimes it is left without any way forward, so you can imagine. It is very frustrating (R8).

\section{Strategic partnerships among industry stakeholders}

Despite the perceived absence of stakeholders in the national government that might lead to the impeding of stakeholder collaboration across the role players in sport and destination branding organisations, there was a clear indication, across the respondents, that having strategic partnerships with both national and international businesses is extremely important to the sustainability of home-grown sport events, and to future marketing and leveraging practices. From a sport event perspective, notable strategic partnerships have been realised between sport event organisers and international event-related businesses. For example, the major event organiser of the Cape Town Cycle Tour has established strategic relations with international event organisers, the Prudential Ride London, in the United Kingdom (UK), in order to market the Cape Town Cycle Tour at the largest cycling event in the UK. At the same time, the event has also formed strategic relations with other international major sport events, such as the Five Boro Bike Race in the United States, the Vätternrundan in Sweden, the Etape Du Tour in France, and the Gran Fondo Campagnolo Roma in Italy, for similar branding benefits. As a result of the strategic partnerships concerned, the Cycle Tour is now able to lever collectively in terms of a database of approximately two million people, who are all interested in cycling. From a cycling perspective, the stakeholders are able to form an association called The World Association of Cycling Events (WACE), which allows each event organiser to market their event through the others' databases. The benefits of the international relationship so formed show promise for the weak South African currency (ZAR or Rand) in terms of international marketing, as well as in terms of direct promotion to healthy individuals, who have adopted an outdoor lifestyle, who are sporty, and who travel, as recognised by a key informant in terms of the organising of major sport and events.

A key informant involved in sport event marketing gave insight into the partnership in the following words:

Strategic partnering is huge, it is immeasurable. Look what you can do for your country through your event, not just for the event, but also [for] your city and country. You bring in these tourists, and they see what South Africa has to offer. We have this partnership with WACE to market directly to event participants and their families. So it works for me, as we are leveraging the event to market the country through these other events around the world ... So, strategic partnerships are absolutely key (R4).

Another key informant in sport event marketing emphasised the importance of strategic partnerships, in particular with the media, and noted that, through such media platforms as television and magazine broadcasting agents, their event could reach, and attract, new international markets to South Africa, as well as derive some form of insight into the destination's brand image through event hosting. The key informant in sport event marketing argued:

We have strategic partnerships with the National Geographic Channel (a cable/satellite television network), and I am busy with a partnership with Bloomberg (a newspaper and magazine media source) to market South Africa through our event. We don't have an office in the Middle East, for instance, but, through these 
partnerships, the Middle East becomes a target market, and we use these [i.e. the] variety of media platforms to get the message of South Africa across (R8).

While R4 and R8 demonstrated their strategic partnerships with their international partners for purposes of sport event leveraging, from a South African perspective, strategic partnerships were believed to depend on stakeholder objectives and various mandates in terms of their business operations. Taks (2013) underscores that, as non-mega events occur more frequently than do mega-events, and are coupled with their accessibility to a wide variety of host cities and towns, they require tight local partnerships and human resources for their staging. However, in terms of the previous discussion on the absence of the NDT, it is plausible that strategic partnerships, in terms of collaborative relationships between sport and national tourism organisations, are lacking. R5 provided some insight into possible reasons for the lack of national government involvement, by alluding to the varied objectives across stakeholder (public and private) groups. The key informant in national government in sport and recreation argued that, unless their predefined objectives are aligned towards the same outcome, the relationship between public and private stakeholder groups will remain elusive. The key informant stated:

Remember, from a business perspective, major events seek to make profit, whereas the objective for government is using sport and events to achieve social development like job creation, priorities in education and poverty, and those type[s] of things, but events have to [have the] ability to create and sustain jobs. Those are very different objectives. It [partnership on a national level] will not work and be mutually beneficial for both, as [the] objectives [concerned] vary (R5).

While such statements are seemingly true, they do not justify the absence of national involvement in major event leveraging, especially since the above is achieved in other, more developed nations, like Australia, with their successful utilisation of sport events involving all role players. For reasons such as the above-mentioned, it makes sense that the stakeholders in sport events would prefer to partner strategically with other businesses with similar objectives. Consequently, despite the varied strategic objectives of the stakeholders in sport event organising and the government, in terms of their respective mandates, it is clear that, in connection with the utilising of sport for destination branding, the imperative for mutual objectives lies in the elicitation of funding and support for local socio-economic enhancement. The imperative also lies in establishing strategic public and private partnerships, so as to combat unique social challenges, and so as to cultivate the event and destination branding, which are believed to be two important means for developing destination brands in [terms of] the developing country context.

\section{IMPLICATIONS AND CONCLUSION}

The purpose of the current paper was to determine the views and challenges of industry stakeholders when considering the utility of non-mega events for destination branding. On the basis of the results and discussions concerned, the following key conclusions and recommendations are made for stakeholders in developing contexts. The results and discussions clearly show that sport events are significant boosters for destination brand promotion and, more importantly, for the enhancement of socioeconomic development for destinations in both the developed and the developing contexts. For the developing destinations, however, the strategic utilisation of sport is emphasised in such policies as local event strategies for the establishing of brand positioning for global competitiveness. Both sport and non-sport events contribute to such policies, which implies the significance of events, both sporting and otherwise, for the securing of destination brand 
benefits. For South Africa, stakeholders involved in destination branding through sport go beyond the primary role players in sport organising committees and tourism and destination branding organisations. The significant role of the media as a key stakeholder is particularly emphasised to portray not only the destination brand through broadcasting, but also to reach out to, and to attract, new international markets to South Africa, as well as to derive some form of insight into the destination's brand image through event hosting. The above is especially important due to the perpetuation of the social issues regarding the developing nations, and the South African brand in particular, through the making of regular media broadcasts. To eradicate such media challenges, the strategic partnership between sport and/or destination branding organisations and the media is seen as imperative. Furthermore, when considering sport for purposes of tourism and destination branding, strategic collaboration between the sport event organisation and the national tourism governments is critical. Beyond the strategic partnering of stakeholders with similar objectives, it is clear from the discussion that stakeholders with varied objectives (public and private) can complement each other on the nature of the sport tourism event industry. For example, sport event organisers complement the national imperative in their aim to enhance job creation and economic and social development through event hosting, and, to reciprocate, the national government supports sport events in their marketing to both the national and the international sport tourism markets. The effective collaboration between public and private stakeholders has a bearing on the marketing performance of nonmega events, and, likewise, on the socio-economic development of the South African brand.

The present study makes a modest theoretical contribution by adding new insights to the stakeholder theory, through uncovering the multiple stakeholder roles involved, in particular in areas of destination branding. In the areas concerned, an additional group of stakeholders is considered in terms of sport, as an important part of destination branding practices. In relation to non-mega events, the findings present insights into stakeholder roles, contributions and objectives in terms of destination branding regarding the utility of sport events, which contributes to the new perspectives that have been gained into strategic stakeholder partnerships and collaborations, in terms of providing evidence of non-mega events for developing destinations, which are often neglected in the extant sport and destination branding literature. The current study further offers practical significance for South African stakeholders, in providing guidance for the utilising of sport events for tourism and destination branding. Moreover, the study confirms, through definitive sport, brand and tourism stakeholder perceptions that a shared commitment from all role players, especially those at a national level, is imperative to the growth and stimulation of all-inclusive and destination brand promotion, as has similarly been reported by such researchers as Hankinson (2010). It further separates the South African brand from the developing nations by recognising the absence of the strategic alignment of predefined objectives between the public and private stakeholders in major events and the national departments concerned, leading to the elusiveness of strategic brand alignment. While the study provides the starting point for an empirical investigation into the utility of sport for the destination branding benefits to be gained in the developing context, critical analysis into a specific major sport event case study could provide enhanced understanding and deepen the insight into best practices for securing effective leveraging and strategic partnerships. The above could be of relevance not only to the wide-ranging major event industry, but also to stakeholder confidence in national and international departments for the South African destination as a whole.

\section{Acknowledgments}

This paper was developed on the basis of a doctoral thesis, submitted to the University of Johannesburg, by the same authors. 


\section{REFERENCES}

Allan, M. (2011). The leadership challenge. In Destination Brands: Managing Place Reputation. Edited by Morgan, N., Pritchard, A., \& Pride, R. 3rd ed. Oxford: Butterworth-Heinemann, pp. 81-90.

Anholt, S. (2005). Some important distinctions in place branding. Place Branding, vol. 1, no. 2, pp. 116-121.

Bob, U. \& Swart, K. (2010). Sport events and social legacies. Alternation, vol. 17, pp. 72-95.

Brown, G., Chalip, L., Jago, L., \& Mules, T. (2004). Developing brand Australia: Examining the role of events. In Destination Branding: Creating the Unique Destination Proposition. Edited by Morgan, N., Pritchard, A., \& Pride, R. Revised 2nd edition. Oxford: Elsevier, pp. 279-299.

Chalip, L. (2004). Beyond impact: A general model for host community event leverage. In Sport Tourism: Interrelationships, Impacts and Issues. Edited by Ritchie, B.W., \& Adair, D. London: Channel View, pp. 226-252.

Chalip, L., Green, B.C. \& Hill, B. (2003). Effects of sport event media on destination image and intention to visit. Journal of Sport Management, vol. 17, pp. 214-234.

Chalip, L. (2014). From legacy to leverage. In Leveraging Legacies from Sports Mega-events: Concepts and Cases. Edited by Grix, J. Basingstoke: Palgrave Macmillan, pp. 2-12.

Clarkson, M.B.E. (1995). A stakeholder framework for analysing and evaluating corporate social performance. Academy of Management Review, vol. 20, no. 1, pp. 92-117.

Cornelissen, S., Bob, U., \& Swart, K. (2011). Towards redefining the concept of legacy in relation to sport megaevents: Insights from the 2010 FIFA World Cup. Development South Africa, vol. 28, no. 3, pp. 307-318.

De Chernatony, L. \& Riley, D.F. (1998). Defining a 'brand': Beyond the literature with expert interpretations. Journal of Marketing Management, vol. 14, pp. 417-443.

De Chernatony, L. \& Segal-Horn, S. (2001). Building on services: Characteristics to develop successful services brands. Journal of Marketing Management, vol. 17, pp. 645-670.

Donaldson, T. \& Preston, L.E. (1995). The stakeholder theory of the corporation: Concepts, evidence and implications. Academy of Management Review, vol. 20, no. 1, pp. 65-91.

Fan, Y. (2010). Branding the nation: Towards a better understanding. Journal of Place Branding and Public Diplomacy, vol. 6, pp. 97-103.

Freire, J. (2014). Editorial: Place branding in Africa. Place Branding and Public Diplomacy, vol. 10, pp. 32-34.

Fyall, A. (2011). The partnership challenge. In Destination Brands: Managing Place Reputation. Edited by Morgan, N., Pritchard, A., \& Pride, R. 3rd ed. Oxford: Butterworth-Heinemann, pp. 91- 103.

Garcia, J.A., Gomez, M., \& Molina, A. (2012). A destination branding model: An empirical analysis based on stakeholders. Tourism Management, vol. 33, pp. 646-661.

Getz, D., \& Page, S. J. (2016). Progress and prospects for event tourism research. Tourism Management, vol. 52, pp. 593-631.

Gibson, H.J., Qi, X.C., \& Zhang, J.J. (2008). Destination image and intent to visit China and the 2008 Beijing Olympic Games. Journal of Sport Management, vol. 22, no. 4, pp. 427-450.

Grix, J. (2012). 'Image' leveraging and sport mega-events: Germany and the 2006 FIFA World Cup. Journal of Sport and Tourism, vol. 17, no. 4, pp. 289-312.

Hankinson, G. (2004). Relational network brands: Towards a conceptual model of place brands. Journal of Vacation Marketing, vol. 10, no. 2, pp. 109-121.

Hankinson, G. (2010). Place branding research: A cross-disciplinary agenda and views of practitioners. Journal of Place and Public Diplomacy, vol. 6, no. 4, pp. 300-315.

Higham, J., \& Hinch, T. (2009). Sport and tourism: Globalisation, mobility and identity. Oxford: Butterworth Heinemann.

Houghton, J.P., \& Stevens, A. (2011). City branding and stakeholder engagement. In City Branding: Theory and Cases. Edited by Dinnie, K. London: Palgrave McMillan, pp. 45-53.

Hemmonsbey, J., \& Knott, B. (2016). Branding an African city through sport: The role of stakeholder engagement. African Journal of Hospitality, Tourism and Leisure, vol. 5, no 3, pp.1-14.

Hemmonsbey, J., \& Tichaawa, T. (2018). The effects of major sport event leveraging for tourism and destination branding: The case of South Africa as an emerging destination. GeoJournal of Tourism and Geosites, vol 21, no 1, pp. 213-282.

Hemmonsbey, J., Tichaawa, T., \& Knott, B. (2018). Conceptual framework for strategic destination branding through leveraging home-grown sport events. South African Journal for Research in Sport, Physical Education and Recreation, vol 40, no 2, pp. 81-98.

Ilieș, A., Wendt, J.A., Ilieș, D.C., Herman, G.V., Ilieș, M., \& Deac, A.L. (2016). The patrimony of wooden churches, built between 1531 and 2015, in the Land of Maramureș, Romania. Journal of Maps, Volume 12, 2016, pp 597-602 - Issue sup1 (http://dx.doi.org/10.1080/17445647.2016.1243075).

Ilies, D.C., Buhas, R., Ilies, M., Ilies, A., Gaceu, O., Pop, A.C., Marcu, F., Buhas, S.D., Gozner, M., \& Baias, S. (2018). Sport Activities and Leisure in Nature 2000 Protected Area - Red Valley, Romania. Journal of Environmental Protection and Ecology, 19, No 1, 367-372.

Jago, L., Chalip, L., Brown, G., Mules, T., \& Ali, S. (2003). Building events into destination branding: Insights from experts. Event Management, vol. 8, no. 1, pp. 3-14.

Kaplanidou, K., \& Gibson, H. (2010). Predicting behavioural intentions of active event sport tourists: The case of a small scale recurring sports event. Journal of Sport \& Tourism, vol. 15, pp. 163-179. 
Kaplanidou, K. (2007). Affective event and destination image: Their influence on Olympic travelers' behavioral intentions. Event Management, vol. 10, pp. 159-173.

Kellett, P., Hede, A., \& Chalip, L. (2008). Social policy for sport events: Leveraging (relationships with) sport teams from other nations for community benefit. European Sport Management Quarterly, vol. 8, no. 2, pp. 101-121.

Knott, B., Fyall, A., \& Jones, I. (2013). The nation-branding legacy of the 2010 FIFA World Cup for South Africa. Journal of Hospitality Marketing \& Management, vol. 22, no. 6, pp. 569-595.

Lichrou, M., O'Malley, L., \& Patterson, M. (2010). Narratives of a tourism destination: Local particularities and their implications for place marketing and branding. Place Branding and Public Diplomacy, vol. 6, no. 2, pp. 134-144.

Louro, M., \& Cunha, P. (2001). Brand management paradigms. Journal of Marketing Management, vol. 17, no. 7-8, pp. 849-887.

Mohammadi, A., \& Jazaei, M. (2016). Reviewing the sport tourism, push and pull factors in Zanjar province, Iran. International Journal of Research in Social Sciences and Humanities, vol. 6, no. 3, pp. 2249-4671.

Morgan, N., Pritchard, A., \& Pride, R. (2002). Destination Branding: Creating the Unique Destination Proposition. Oxford: Butterworth--Heinemann.

Morgan, N.J., Pritchard, A., \& Piggott, R. (2003). Destination branding and the role of the stakeholders: The case of New Zealand. Journal of Vacation Marketing, vol. 9, no. 3, pp. 285-299.

Morgan, N.J., Pritchard, A., \& Pride, R. (2010). Destination Branding. 2nd rev. ed. Oxford: Elsevier.

Munien, S., \& Majola, M.C. (2012). Rural community perceptions of the 2010 FIFA World Cup: A case study of the Izibukwana community, Kwazulu-Natal. African Journal for Physical, Health Education, Recreation and Dance, September (Supplement 1), pp. 53-61.

Nyikana, S., \& Tichaawa, T.M. (2018a). Contextualising sport and tourism in Central Africa: Prospects and challenges. GeoJournal of Tourism and Geosites, vol. 23, no. 3, pp. 895-909.

Nyikana, S., \& Tichaawa, T.M. (2018b). Sport tourism as a local economic development enhancer for emerging destinations. EuroEconomica, vol. 37, no. 2, pp. 70-83.

O’ Brien, D., \& Chalip, L. (2008). Sport events and strategic leveraging: Pushing towards the triple bottom line. In Tourism Management: Analysis, Behaviour and Strategy. Edited by Woodside, A.G., \& Martin, D. Washington, DC: CABI, pp. 318-338.

Ooi, C.S., \& Pedersen, J.S. (2010). City branding and film festivals: Re-evaluating stakeholder's relations. Place Branding and Public Diplomacy, vol. 6, no. 4, pp. 316-332.

Palmer, A. (2002). Destination branding and the Web. In Destination Branding: Creating the Unique Destination Proposition. Edited by Morgan, N., Pritchard, A., \& Pride, R. Oxford: Butterworth Heinemann.

Paskaleva-Shapira, K.A. (2007). New Paradigms in City Tourism Management: Redefining Destination Promotion. Journal of Travel Research, vol. 46, no. 1, pp. 108-114.

Sheehan, L., Richie, J.R.B., \& Hudson, S. (2007). The destination promotion triad: Understanding asymmetric stakeholder independencies among the city, hotels and DMO. Journal of Travel Research, vol. 46, no. 1, pp. 64-74.

Smith, A. (2014). Leveraging sport mega-events: New model or convenient justification? Journal of Policy Research in Tourism, Leisure and Events, vol. 6, no. 1, pp. 15-30.

Taks, M. (2013). Social sustainability of non-mega sport events in a global world. European Journal for Sport and Society, vol. 10, no. 2, pp. 121-141.

Taks, M., Chalip, L. \& Green, B. C. (2015). Impacts and strategic outcomes from non-mega sport events for local communities. European Sport Management Quarterly, vol. 15, no. 1, pp. 1-6.

Tichaawa, T.M., \& Bama, H.K.N. (2012). Green Point residents' perceptions of the 2010 FIFA World Cup: A post-event analysis. African Journal for Physical, Health Education, Recreation and Dance, (Supplement 1), pp. 22-32.

Tichaawa, T.M., \& Bob, U. (2015). Leveraging mega-events beyond the host nation: A case study of the 2010 FIFA World Cup African Legacy Programme in Cameroon and Nigeria. Leisure Studies, vol. 34, no. 6, pp. 742-757.

Tichaawa, T.M., Bob, U., \& Swart, K. (2018). Africa and sports tourism. In Sport in the African world. Edited by Nauright, J., \& Amara, M. London: Routledge.

Todd, L., Leask, A., \& Ensor, J. (2017). Understanding primary stakeholders' multiple roles in hallmark event tourism management. Tourism Management, vol. 59, pp. 494-509.

Trueman, M., Klemm, M., \& Giroud, A. (2004). Can a city communicate? Bradford as a corporate brand. Corporate Communications: An International Journal, vol. 9, no. 4, pp. 317-330.

Turco, D.M., Tichaawa, T.M., Moodley, V., Munien, S., Jaggerneth, J., \& Stofberg, Q.S. (2012). Profiles of foreign visitors attending the 2010 FIFA World Cup in South Africa. African Journal for Physical, Health Education, Recreation and Dance, September (Supplement 1), pp. 73-80.

Waligo, V. M., Clarke, J., \& Hawkins, R. (2013). Implementing sustainable tourism: A multi-stakeholder involvement management framework. Tourism Management, vol. no 36, pp. 342-353.

Wood, L. (2000). Brands and brand equity: Definition and management. Management Decision, vol. 38, no. 9, pp. 662-669.

Xie, H.Y., \& Boggs, D.J. (2006). Corporate branding versus product branding in emerging markets: A conceptual framework. Marketing Intelligence and Planning, vol. 24, no. 4, pp. 347-364.

Submitted:

10.01.2019
Revised:

27.03.2019
Accepted and published online 29.03.2019 